\title{
An attempt to determine the chemical composition of reservoir waters from Polish Lower Paleozoic shale formations
}

\begin{abstract}
The exact chemical composition of reservoir water from Lower Paleozoic shale formations is not known. Reservoir fluids produced during the tests performed in these formations contain a considerable amount of flowback fluid. Taking into consideration the results of the chemical composition monitoring of those fluids we observed a gradual growth of $\mathrm{Cl}^{-}, \mathrm{Na}^{+}, \mathrm{Ca}^{2+}, \mathrm{Mg}^{2+}$, and $\mathrm{Br}^{-}$ion contents, approaching characteristic values of Cambrian reservoir water. In addition, the analysis of the hydrochemical indices of the examined liquids indicates the chemical similarity of Ordovician-Silurian waters to Cambrian waters.
\end{abstract}

Key words: reservoir water, hydrochemical index, Cambrian water.

\section{Próba określenia składu chemicznego wód złożowych z dolno paleozoicznych formacji tupkowych}

\begin{abstract}
Jak dotychczas, nie jest znany dokładny skład chemiczny wód złożowych z łupkowych formacji dolnego paleozoiku. Wydobywane na powierzchnię w trakcie testów produkcyjnych płyny złożowe zawierają znaczny udział płynów pozabiegowych (cieczy po zabiegach hydraulicznego szczelinowania). W oparciu o przeprowadzone badania monitoringu składu chemicznego tych cieczy zauważono stopniowy wzrost udziału jonów: $\mathrm{Cl}^{-}, \mathrm{Na}^{+}, \mathrm{Ca}^{2+}, \mathrm{Mg}^{2+}$ i Br w kierunku zbliżania się do wartości charakterystycznych dla wód kambryjskich. Również analiza wskaźników hydrochemicznych badanych cieczy wydaje się wskazywać na podobieństwo chemiczne wód ordowicko-sylurskich $\mathrm{z}$ wodami kambru.
\end{abstract}

Słowa kluczowe: wody złożowe, wskaźnik hydrochemiczny, wody kambru.

\section{Introduction}

If the chemical composition and phase properties of hydrocarbon liquids from the Lower Paleozoic shale formations in the wells sampled so far have already been determined [8], the recognition of a representative chemical composition of reservoir water encounters specific difficulties. Shale type reservoirs show a number of unique features. The lack of a determined level of subjacent water is one of them, while the content of bound water may vary in very broad limits [4]. The hitherto performed practice of fracturing treatments performed in Polish shale formations shows that from 13 to $44 \%$ of previously pumped in fluids flow back to the surface (figures for horizontal wells). For vertical wells this percentage is even higher, and ranges from 24 to $80 \%$ of the pumped in fluids. On average approx. $1.600 \mathrm{~m}^{3}$ of flowback fluid were returned to the surface, but the differences for individual wells were huge, and ranged from $33 \mathrm{~m}^{3}$ to more than $8,000 \mathrm{~m}^{3}$ [10]. The existence of a arge amount of microfractures is the main reason for slow well cleaning. The phenomena of relative permeability, wetting, as well as the tortuosity and complicated course of liquid filtration paths play an important role when removing flowback fluid from them. These phenomena to a large extent delay the process of fluid removal after the performed fracturing treatments. This applies in particular to the matrix, in which a high 
capillary pressure exists [7]. So during the production tests in surface separators for a very long period of time we have obtained a mixture of flowback fluids and reservoir waters. The period of tests has so far not exceeded a few months; as a result the reservoir water extracted to the surface has contained a significant share of flowback fluid, which should, it is presumed, diminish with time. Hence, the exact composition of reservoir waters from the Lower Paleozoic shale formations is not known up to now. In the Hydrochemical and Hydrodynamic Atlas of the Paleozoic and Mesozoic [3] there is no data on the chemism of Ordovician-Silurian waters; it only presents the characteristics of Cambrian and Devonian waters. Analysing the available data [2], the analyses of waters from exploration wells previously made in the area of northern Poland in Silurian, Ordovician, and Cambrian formations have been found. However this is incomplete and scarce data that requires reverification, in particular due to the fact that the samples were taken from formation testers fixed to the drilling pipe and not during production tests.
The knowledge of reservoir waters' chemical composition is necessary to properly determine the method for their disposal. In oil industry they should not be considered waste because they might be applied as a necessary agent in methods of enhance hydrocarbons recovery supporting, especially for crude oil. Their use in the processes of return injection in allows the substantially increasing of the recovery factor of geological reserves. The API regulations [5] should be the model, according to which: "The reservoir water injected during processes of EOR is not waste. This results from the fact that the reservoir water used during the extraction supporting is usefully pumped in again and constitutes an integral part of processes related to the reservoirs of crude oil and natural gas". Apart from environmental issues, the chemical composition of pumped in reservoir waters is also favourable, having a positive impact on the rock and reservoir fluids [11]. Hence, to develop the optimum concepts for the management of hydrocarbons deposits existing in Lower Paleozoic shale formations, considering the environmental aspects, it is necessary to know the composition of reservoir waters existing in those formations.

\section{Monitoring chemical composition changes of the recovered fluid}

Monitoring the chemical composition changes of the fluid recovery from the well during production tests vs. time should allow a gradual recognition of reservoir waters' chemical composition from the fractured shale formations. The above thesis was made assuming a gradual increase in the reservoir waters share in the flowback fluid collected in the surface separators. As presented before, the phenomenon of returning the flowback fluid from the shale formation is a long-term process, and it is especially related to the matrix; nevertheless, the share of flowback fluid in the collected stream will decrease in favour of an increasing share of reservoir waters.

Based on the above premises, the work related to monitoring the course of chemical composition changes of fluids recovery during the production tests in selected wells was carried out within the Blue Gas Project [9]. The monitored changes of the chemical composition of fluid samples recovery during the ongoing production test were compared with the chemical composition of the initial fracturing liquid used in a specific treatment and with the chemical composition of Cambrian waters from the B- 8 well.

It has been considered advisable to check to what extent the chemical composition of consecutive samples of the fluid from the tested wells, changing with the time of taking, is close to the known composition of Cambrian waters, because an assumption was made that the Ordovician and Silurian waters, in terms of chemistry, should be close to the Cambrian waters. It should be emphasised that the Cambrian reservoir levels in the land and sea part of the Baltic syneclise are generally well insulated. The sealing strata consist of clay-mudstone packages in the roof part of the Middle Cambrian, of a clay complex of the Upper Cambrian, then of clay layers of the Ordovician, and finally a thick, in places exceeding $3000 \mathrm{~m}$, series of clay-mudstone Silurian deposits. In the eastern part the Cambrian sealing is admittedly missing, but the insulation is provided by the Ordovician strata [1].

Nevertheless, an assumption of Ordovician-Silurian origin of reservoir fluids existing in the Cambrian formations is frequently made, which could be laterally filled with hydrocarbons generated in the Lower Paleozoic. The clay-shale Silurian formations fulfil the role of a series generating hydrocarbons and sealing the reservoirs. They contain a sapropel type organic matter in the amount of $0.5 \div 1.5 \%$ and the coefficient of metamorphosis $R_{o}$ of around $0.65 \div 2.0$. These formations could generate crude oil in the Baltic syneclise, in the Leba uplift, in the Warsaw basin, and in Podlasie [6].

Following changes of the chemical composition of the analysed fluid samples from the tested wells (see Figs. 1-14) a clear increase is marked in such ions content as: $\mathrm{Cl}^{-}, \mathrm{Na}^{+}$, $\mathrm{Ca}^{2+}, \mathrm{Mg}^{2+}$, and $\mathrm{Br}$ towards approaching the characteristic values of Cambrian waters. In the case of $\mathrm{Cl}^{-}$ion content, which in Cambrian waters exceeds $100 \mathrm{~g} / \mathrm{dm}^{3}$, in waters collected from the tested wells from the initial values close to 0 after 8 days it reaches the value of $80 \mathrm{~g} / \mathrm{dm}^{3}$. The content of sodium ions in collected fluids reaches and even exceeds the value 


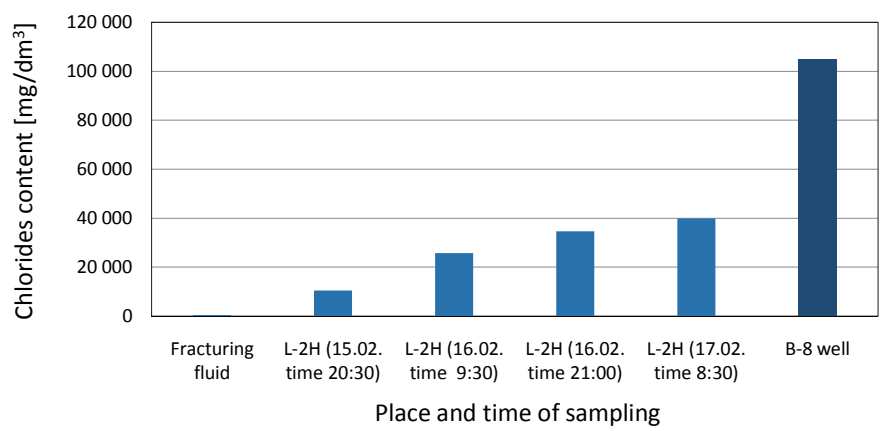

Fig. 1. Comparison of chlorides contents in consecutively taken samples of the fluid from the tested L well, as well as in the fracturing fluid and in the Cambrian reservoir water

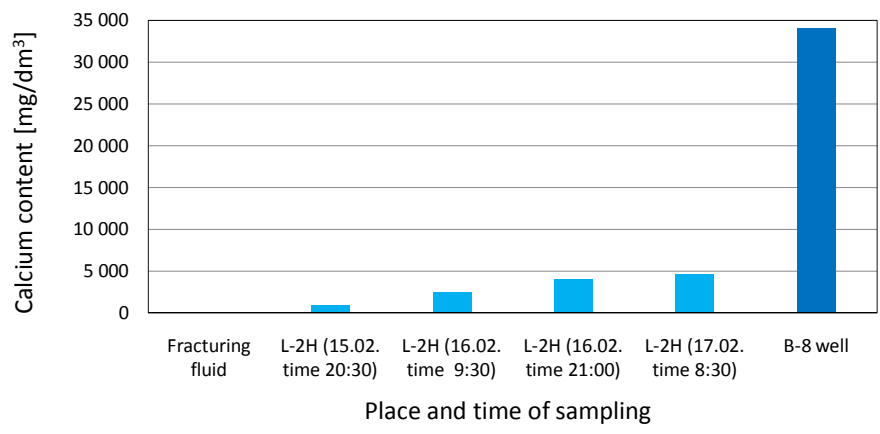

Fig. 3. Comparison of calcium contents in consecutively taken samples of the fluid from the tested $\mathrm{L}$ well, as well as in the fracturing fluid and in the Cambrian reservoir water

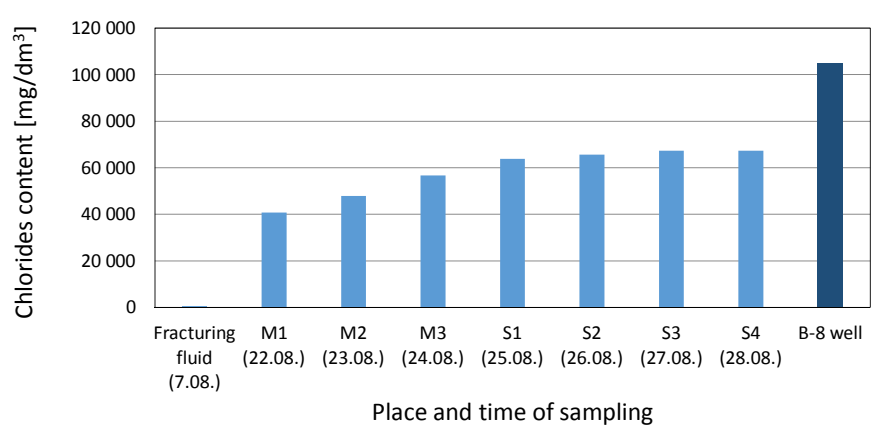

Fig. 5. Comparison of chlorides contents in consecutively taken samples of the flowback fluid from the tested S well, as well as in the fracturing fluid and in the Cambrian reservoir water (stage I)

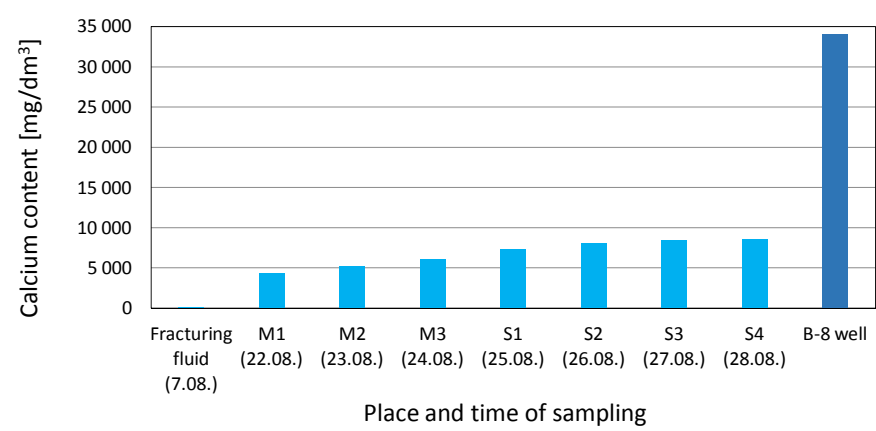

Fig. 7. Comparison of calcium contents in consecutively taken samples of the fluid from the tested S well, as well as in the fracturing fluid and in the Cambrian reservoir water (stage I)

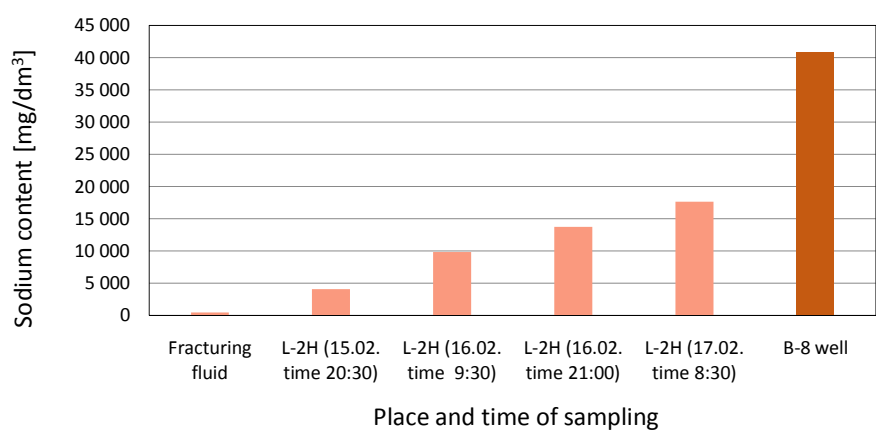

Fig. 2. Comparison of sodium contents in consecutively taken samples of the fluid from the tested $\mathrm{L}$ well, as well as in the fracturing fluid and in the Cambrian reservoir water

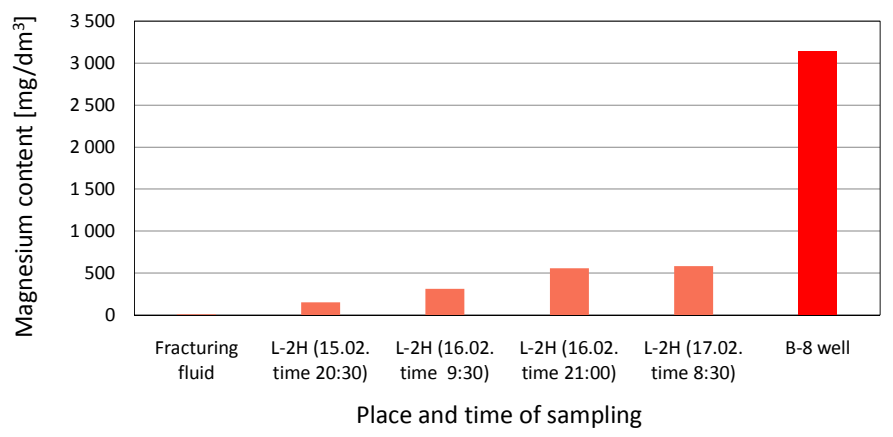

Fig. 4. Comparison of magnesium contents in consecutively taken samples of the fluid from the tested L well, as well as in the fracturing fluid and in the Cambrian reservoir water

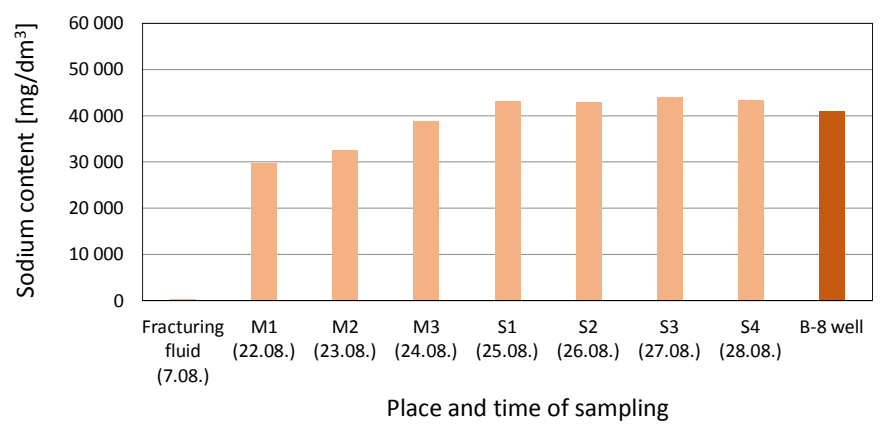

Fig. 6. Comparison of sodium contents in consecutively taken samples of the fluid from the tested S well, as well as in the fracturing fluid and in the Cambrian reservoir water (stage I)

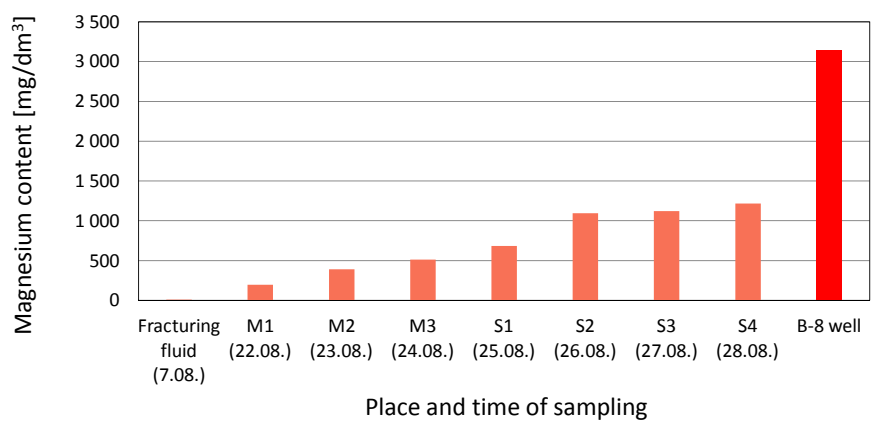

Fig. 8. Comparison of magnesium contents in consecutively taken samples of the fluid from the tested $\mathrm{S}$ well, as well as in the fracturing fluid and in the Cambrian reservoir water (stage I) 


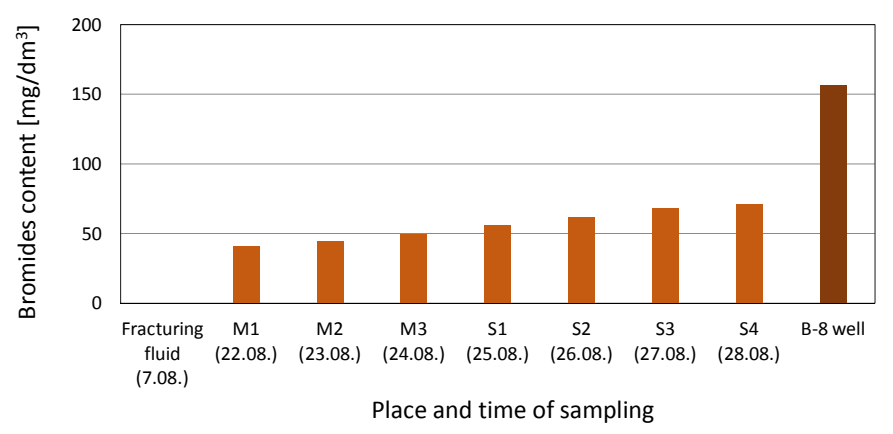

Fig. 9. Comparison of bromide ions contents in consecutively taken samples of the flowback fluid from the tested $\mathrm{S}$ well, as well as in the fracturing fluid and in the Cambrian reservoir water (stage I)

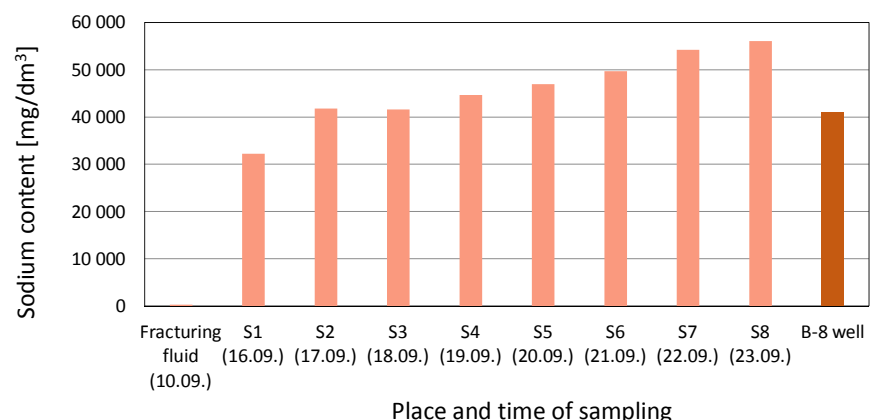

Fig. 11. Comparison of sodium contents in consecutively taken samples of the fluid from the tested S well, as well as in the fracturing fluid and in the Cambrian reservoir water (stage II)

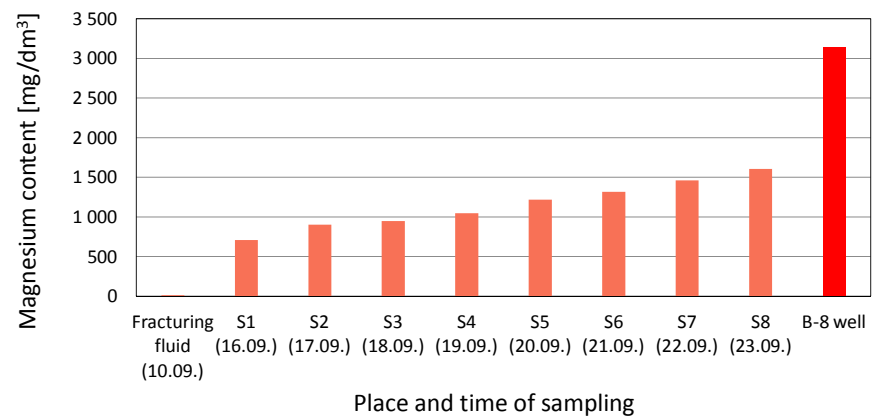

Fig. 13. Comparison of magnesium contents in consecutively taken samples of the fluid from the tested $\mathrm{S}$ well, as well as in the fracturing fluid and in the Cambrian reservoir water (stage II)

of $40 \mathrm{~g} / \mathrm{dm}^{3}$, characteristic of Cambrian waters. The calcium content in Cambrian waters equal to $35 \mathrm{~g} / \mathrm{dm}^{3}$ in the collected waters after 8 days reaches the level of $10 \mathrm{~g} / \mathrm{dm}^{3}$. Then the magnesium ions content in collected waters reaches $1.5 \mathrm{~g} / \mathrm{dm}^{3}$ and also approaches the level of $3 \mathrm{~g} / \mathrm{dm}^{3}$, characteristic

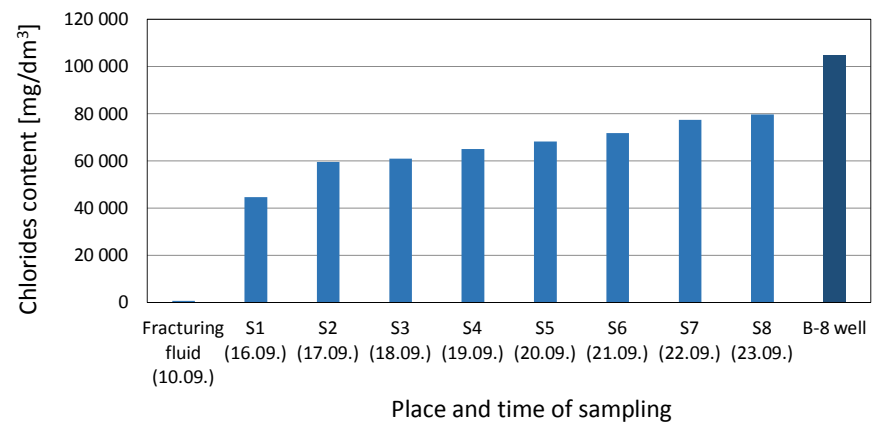

Fig. 10. Comparison of chlorides contents in consecutively taken samples of the fluid from the tested S well, as well as in the fracturing fluid and in the Cambrian reservoir water (stage II)

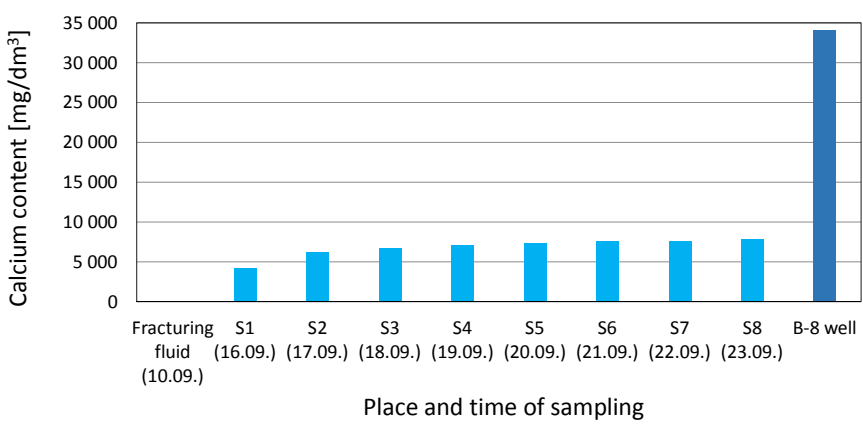

Fig. 12. Comparison of calcium contents in consecutively taken samples of the fluid from the tested $\mathrm{S}$ well, as well as in the fracturing fluid and in the Cambrian reservoir water (stage II)

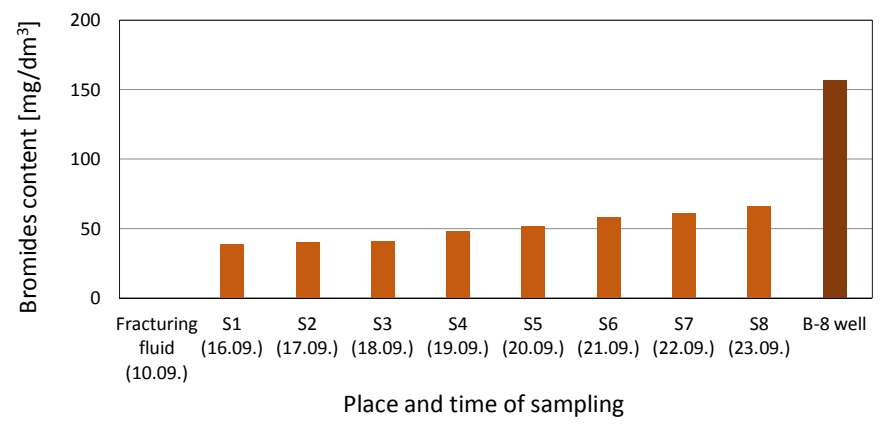

Fig. 14. Comparison of bromide ions contents in consecutively taken samples of the flowback fluid from the tested S well, as well as in the fracturing fluid and in the Cambrian reservoir water (stage II)

of Cambrian waters. The bromides content, which in the fracturing fluid is zero, in the consecutive samples of fluid collected from the tested $\mathrm{S}$ well reaches values around $70 \mathrm{mg} / \mathrm{dm}^{3}$, approaching $150 \mathrm{mg} / \mathrm{dm}^{3}$, characteristic of Cambrian waters.

\section{Hydrochemical indices of tested fluids}

Hydrochemical indices are useful criteria to determine the genetic water types and to assess conditions of hydrocarbons behaviour. The Sulin classification is used for waters accompanying the hydrocarbons reservoirs, which, because of the chemical composition and the metamorphism degree, distinguishes four water types: 
1) hydrocarbonate-sodium type $\left(\mathrm{HCO}_{3}{ }^{-}-\mathrm{Na}^{+}\right)$for zones with intensive waters exchange,

2) sulphate-sodium type $\left(\mathrm{SO}_{4}{ }^{2-}-\mathrm{Na}^{+}\right)$for the transition zone,

3) chloride-magnesium type $\left(\mathrm{Cl}^{-}-\mathrm{Mg}^{2+}\right)$ for old relict sedimentation waters,

4) chloride-calcium type $\left(\mathrm{Cl}^{-}-\mathrm{Ca}^{2+}\right)$ for most insulated waters of high mineralisation, related to crude oil reservoirs.

Because of too small diversification of waters marking the hydrodynamic zoning of the reservoirs, five classes were additionally distinguished in the last group. For class 4 the values of index $\mathrm{rNa} / \mathrm{rCl}=0.65 \div 0.50$ were classified as a prospective zone, and for class 5 the values of $\mathrm{rNa} / \mathrm{rCl}<0.50$ were classified as a very prospective zone.

The following Tables 1, 2, and 3 present values of the Sulin hydrodynamic indices for fluid samples consecutively taken from the tested wells $\mathrm{S}$ and $\mathrm{L}$, as well as from the fracturing fluid and from the Cambrian reservoir water. The values satisfying the Sulin criteria of specific water type are marked with blue characters.

The Cambrian reservoir water marked with the symbol B- 8 (see Table 1) corresponds to the chloride-calcium type index and class four. This means that this is a relict water of very

Table 1. Values of Sulin hydrodynamic indices for consecutively taken fluid samples from the test S well (stage I) and from the fracturing fluid, and from the Cambrian reservoir water

\begin{tabular}{|c|c|c|c|c|c|c|c|c|c|c|}
\hline \multicolumn{2}{|c|}{ Sulin water types } & $\begin{array}{l}\text { Fracturing } \\
\text { fluid }\end{array}$ & $\begin{array}{c}\text { M1 } \\
22 / 08 / 2014\end{array}$ & $\begin{array}{c}\text { M2 } \\
23 / 08 / 2014\end{array}$ & $\begin{array}{c}\text { M3 } \\
24 / 08 / 2014\end{array}$ & $\underset{25 / 08 / 2014}{\text { S1 }}$ & $\begin{array}{c}\text { S2 } \\
26 / 08 / 2014\end{array}$ & $\begin{array}{c}\text { S3 } \\
27 / 08 / 2014\end{array}$ & $\begin{array}{c}\text { S4 } \\
28 / 08 / 2014\end{array}$ & $\begin{array}{l}\text { B-8 } \\
\text { well }\end{array}$ \\
\hline \multicolumn{11}{|c|}{ Hydrocarbonate-sodium type } \\
\hline $\mathrm{rNa} / \mathrm{rCl}$ & $>1$ & 0.9 & 1.1 & 1.05 & 1.05 & 1.04 & 1.01 & 1.01 & 0.68 & 0.99 \\
\hline $\mathrm{rNa}-\mathrm{rCl} / \mathrm{rSO}_{4}$ & $>1$ & -5.4 & 37.5 & 20.46 & 27.59 & 38.02 & 5.40 & 4.73 & -120.88 & -7.96 \\
\hline \multicolumn{11}{|c|}{ Sulphate-sodium type } \\
\hline $\mathrm{rNa} / \mathrm{rCl}$ & $>1$ & 0.9 & 1.1 & 1.05 & 1.05 & 1.04 & 1.01 & 1.01 & 0.68 & 0.99 \\
\hline $\mathrm{rNa}-\mathrm{rCl} / \mathrm{rSO}_{4}$ & $<1$ & -5.4 & 37.5 & 20.46 & 27.59 & 38.02 & 5.40 & 4.73 & -120.88 & -7.96 \\
\hline \multicolumn{11}{|c|}{ Chloride-magnesium type } \\
\hline $\mathrm{rNa} / \mathrm{rCl}$ & $<1$ & 0.9 & 1.1 & 1.05 & 1.05 & 1.04 & 1.01 & 1.01 & 0.68 & 0.99 \\
\hline $\mathrm{rCl}-\mathrm{rNa} / \mathrm{rMg}$ & $<1$ & 1.8 & -8.5 & -2.07 & -2.06 & -1.38 & -0.16 & -0.13 & 7.46 & 0.18 \\
\hline \multicolumn{11}{|c|}{ Chloride-calcium type } \\
\hline $\mathrm{rNa} / \mathrm{rCl}$ & $<1$ & 0.9 & 1.1 & 1.05 & 1.05 & 1.04 & 1.01 & 1.01 & 0.68 & 0.99 \\
\hline $\mathrm{rCl}-\mathrm{rNa} / \mathrm{rMg}$ & $>1$ & 1.8 & -8.5 & -2.07 & -2.06 & -1.38 & -0.16 & -0.13 & 7.46 & 0.18 \\
\hline
\end{tabular}

Table 2. Values of Sulin hydrodynamic indices for consecutively taken fluid samples from the test S well (stage II) and from the fracturing fluid

\begin{tabular}{|c|c|c|c|c|c|c|c|c|c|c|}
\hline \multicolumn{2}{|c|}{ Sulin water types } & $\begin{array}{l}\text { Fracturing } \\
\quad \text { fluid }\end{array}$ & $\begin{array}{c}\text { S1 } \\
16 / 09 / 2014\end{array}$ & $\begin{array}{c}\mathrm{S} 2 \\
17 / 09 / 2014\end{array}$ & $\begin{array}{c}\text { S3 } \\
18 / 09 / 2014\end{array}$ & $\begin{array}{c}\text { S4 } \\
19 / 09 / 2014\end{array}$ & $\begin{array}{c}\text { S5 } \\
20 / 09 / 2014\end{array}$ & $\begin{array}{c}\text { S6 } \\
21 / 09 / 2014\end{array}$ & $\begin{array}{c}\text { S7 } \\
22 / 09 / 2014\end{array}$ & $\begin{array}{c}\text { S8 } \\
23 / 09 / 2014\end{array}$ \\
\hline \multicolumn{11}{|c|}{ Hydrocarbonate-sodium type } \\
\hline $\mathrm{rNa} / \mathrm{rCl}$ & $>1$ & 0.60 & 1.11 & 1.08 & 1.05 & 1.06 & 1.06 & 1.07 & 1.08 & 1.08 \\
\hline $\mathrm{rNa}-\mathrm{rCl} / \mathrm{rSO}_{4}$ & $>1$ & -6.63 & 56.76 & 60.15 & 36.01 & 45.08 & 50.12 & 67.31 & 89.16 & 99.70 \\
\hline \multicolumn{11}{|c|}{ Sulphate-sodium type } \\
\hline $\mathrm{rNa} / \mathrm{rCl}$ & $>1$ & 0.60 & 1.11 & 1.08 & 1.05 & 1.06 & 1.06 & 1.07 & 1.08 & 1.08 \\
\hline $\mathrm{rNa}-\mathrm{rCl} / \mathrm{rSO}_{4}$ & $<1$ & -6.63 & 56.76 & 60.15 & 36.01 & 45.08 & 50.12 & 67.31 & 89.16 & 99.70 \\
\hline \multicolumn{11}{|c|}{ Chloride-magnesium type } \\
\hline $\mathrm{rNa} / \mathrm{rCl}$ & $<1$ & 0.60 & 1.11 & 1.08 & 1.05 & 1.06 & 1.06 & 1.07 & 1.08 & 1.08 \\
\hline $\mathrm{rCl}-\mathrm{rNa} / \mathrm{rMg}$ & $<1$ & 8.16 & -2.47 & -1.87 & -1.16 & -1.28 & -1.19 & -1.25 & -1.47 & -1.44 \\
\hline \multicolumn{11}{|c|}{ Chloride-calcium type } \\
\hline $\mathrm{rNa} / \mathrm{rCl}$ & $<1$ & 0.60 & 1.11 & 1.08 & 1.05 & 1.06 & 1.06 & 1.07 & 1.08 & 1.08 \\
\hline rCl-rNa/rMg & $>1$ & 8.16 & -2.47 & -1.87 & -1.16 & -1.28 & -1.19 & -1.25 & -1.47 & -1.44 \\
\hline
\end{tabular}


Table 3. Values of Sulin hydrodynamic indices for consecutively taken fluid samples from the test L well and from the fracturing fluid, and from the Cambrian reservoir water

\begin{tabular}{|c|c|c|c|c|c|c|c|}
\hline Sulin water ty & & Fracturing fluid & $\begin{array}{c}\mathrm{L} \\
15 / 02 / 2013 \\
\text { time: } 20: 30\end{array}$ & $\begin{array}{c}\mathrm{L} \\
16 / 02 / 2013 \\
\text { time: } 9: 30\end{array}$ & $\begin{array}{c}\mathrm{L} \\
06 / 02 / 2013 \\
\text { time: } 21: 00\end{array}$ & $\begin{array}{c}\mathrm{L} \\
\text { 17/02/2013 } \\
\text { time: } 08: 30\end{array}$ & B-8 well \\
\hline Hydrocarbonat & sodi & m type & & & & & \\
\hline $\mathrm{rNa} / \mathrm{rCl}$ & $>1$ & 1.89 & 0.59 & 0.6 & 0.59 & 0.61 & 0.68 \\
\hline $\mathrm{rNa}-\mathrm{rCl} / \mathrm{rSO}_{4}$ & $>1$ & 4.54 & -68.48 & -135.41 & -5680.30 & -129.93 & -120.88 \\
\hline Sulphate-sodiuı & type & & & & & & \\
\hline $\mathrm{rNa} / \mathrm{rCl}$ & $>1$ & 1.89 & 0.59 & 0.60 & 0.59 & 0.61 & 0.68 \\
\hline $\mathrm{rNa}-\mathrm{rCl} / \mathrm{rSO}_{4}$ & $<1$ & 4.54 & -68.48 & -135.41 & -5680.30 & -129.93 & -120.88 \\
\hline Chloride-magn & sium & ype & & & & & \\
\hline $\mathrm{rNa} / \mathrm{rCl}$ & $<1$ & 1.89 & 0.59 & 0.60 & 0.59 & 0.61 & 0.68 \\
\hline rCl-rNa/rMg & $<1$ & -8.77 & 9.46 & 11.50 & 4.60 & 8.24 & 7.46 \\
\hline Chloride-calciu & n typ & & & & & & \\
\hline $\mathrm{rNa} / \mathrm{rCl}$ & $<1$ & 1.89 & 0.59 & 0.60 & 0.59 & 0.61 & 0.68 \\
\hline $\mathrm{rCl}-\mathrm{rNa} / \mathrm{rMg}$ & $>1$ & -8.77 & 9.46 & 11.50 & 4.60 & 8.24 & 7.46 \\
\hline
\end{tabular}

high mineralisation, and values characteristic of class 4 rate it as the prospective zone.

The samples of fluid from the tested $\mathrm{S}$ well in the initial period of collection, i.e. when the share of fracturing fluid is significant, feature hydrodynamic indices characteristic of the hydrocarbonate-sodium type (Table 1 and 2).
At a later stage of collection, when the share of reservoir waters from the shale formations grows, their type changes to the chloride-magnesium type (Table 1), characteristic of old relict sedimentation waters.

In the L well (Table 3) they correspond to the chloride-calcium type, which proves a significant share of reservoir waters.

\section{Summary}

The studies of the chemical composition of fluids containing a large admixture of flowback fluids, obtained during the production tests from the wells opening Lower Paleozoic shale formations show a gradual increase in the share of ions: $\mathrm{Cl}^{-}, \mathrm{Na}^{+}, \mathrm{Ca}^{2+}, \mathrm{Mg}^{2+}$, and $\mathrm{Br}^{-}$towards the characteristic values of Cambrian waters. Because of the lack, so far, of possibilities for the unequivocal determination of the chemism of shale formations reservoir waters, there are premises that Ordovician-Silurian waters are chemically similar to Cambrian waters. This is also confirmed by the analysis of studied fluids' hydrodynamic indices. Monitoring the chemical composition changes of the fluid collected from the well during production tests vs. time should allow a gradual recognition of reservoir waters' chemical composition from the fractured formations.

Please cite as: Nafta-Gaz 2015, no. 11, pp. 877-883, DOI: 10.18668/NG2015.11.10

Article contributed to the Editors 9.09.2015. Approved for publication 20.10.2015.

The article is the result of research conducted in connection with a project: Development of optimum concepts for unconventional deposits management, considering environmental and social aspects, co-funded by the National Centre for Research and Development as part of the programme BLUE GAS - POLISH SHALE GAS. Contract No. BG1/ResDev/13.

\section{Literature}

[1] Andriuszczenko J., Modlinski Z., Puroniene I., Sokołowski A.: Wskazniki ropo- i gazonosnosci $w$ wodach srodkowokambryjskich poziomow zbiornikowych syneklizy baltyckiej. Przegląd Geologiczny 1999, vol. 47, no. 8, pp. 737-739.

[2] Baza danych Geobank z otworów wiertniczych Zakładu Geofizyki Wiertniczej INiG - PIB, Kraków.

[3] Bojarski L.: Atlas hydrochemiczny i hydrodynamiczny paleozoiku i mezozoiku oraz ascensyjnego zasolenia wod podziemnych na Nizu Polskim. Wydawnictwo Państwowego Instytutu Geologicznego 1996.

[4] Ciechanowska M., Matyasik I., Such P., Kasza P., Lubas J.: Uwarunkowania rozwoju wydobycia gazu z polskich formacji tupkowych. Nafta-Gaz 2013, no. 1, pp. 7-17.

[5] Environmental Guidance Document: Waste Management in 
Exploration and Production Operations. 1997API E5 Second edition.

[6] Karnkowski P.: Zloza gazu ziemnego i ropy naftowej w PolsceNiz Polski. Towarzystwo Geosynoptyków GEOS AGH, Krakow 1993, vol. 1.

[7] Kasza P.: Zabiegi hydraulicznego szczelinowania $w$ formacjach lupkowych. Nafta-Gaz 2011, no. 12, pp. 874-883.

[8] Lubas J., Warnecki M., Szuflita S.: Types of reservoir fluids in the polish Lower Paleozoic shale formations. Nafta-Gaz 2015, no. 8, pp. 539-548.

[9] Opracowanie kryteriów i optymalizacja gospodarki wodami zlozowymi. Praca Instytutu Nafty i Gazu - PIB w ramach
Projektu pt. „Opracowanie optymalnych koncepcji zagospodarowania złóż niekonwencjonalnych z uwzględnieniem aspektów środowiskowych". Praca w toku, projekt Blue Gas Polski Gaz Łupkowy.

[10] Serwis Informacyjny Państwowej Służby Geologicznej: Dobre wiesci z otworu Lublewo LEP-1ST1H na Pomorzu; http:// infolupki.pgi.gov.pl/pl/plco-sie-wierci/dobre-wiesci-z-otworu-lublewo-lep-1st1h-na-pomorzu (access on: 15.08.2015).

[11] Sharma M. M., Filoco P. R.: Effect of brine salinity and crude-oil properties on oil recovery and residual saturations. SPE Journal 2000, vol. 5, SPE 65402-PA.

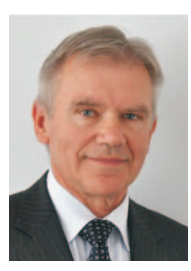

Dr hab. Eng. Jan LUBAŚ

Deputy Director. Hydrocarbon Deposits Exploitation Head of Oil and Gas Institute Krosno Branch Oil and Gas Institute - National Research Institute ul. Lubicz 25 A 31-503 Kraków E-mail:jan.lubas@inig.pl

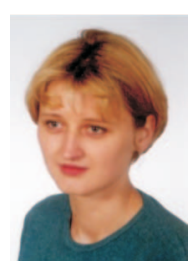

Dorota KLUK M.Sc. Eng.

Senior Technical Research Specialist

Department of Technology for Reservoir Fluids

Exploitation

Oil and Gas Institute - National Research Institute

ul. Lubicz 25 A, 31-503 Kraków

E-mail:dorota.kluk@inig.pl

\section{OFFER}

\section{DEPARTMENT OF DRILLING TECHNOLOGY}

Scope of activity:

- evelopment of the composition and preparation technologies for drilling fluids, completion and workover fluids, cement slurries and binding mixtures for various technical and geological drilling conditions;

- the comprehensive examination and evaluation of new types of chemicals, flushing and binding materials designed for the preparation and regulation of drilling fluids and cement slurries;

- measurement of the technological parameters of drilling fluids and cement stone in normal and high temperature and pressure conditions;

- $\quad$ studies on the impact of drilling fluids on drilled rocks;

- the selection of drilling fluids, cement slurries and buffer fluids in order to improve the effectiveness of borehole cementing;

- service tests for current cementing operations;

- $\quad$ specialised laboratory tests related to determination of: friction coefficient of drilling fluids and

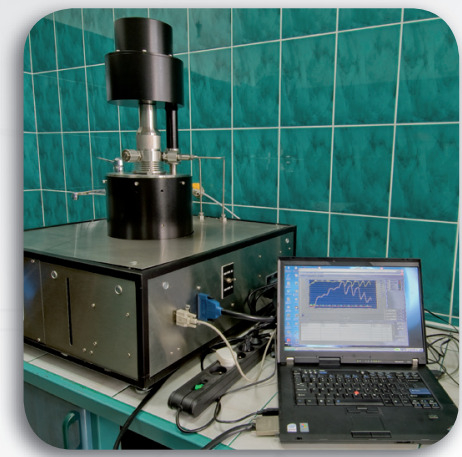
surface tension at the interface, crystallisation temperature and purity of brines, type of emulsion, solid phase sedimentation, effectiveness of cuttings removal in directional and horizontal boreholes and also of mud cakes removal from rocks prior to cementing, resistance to gas migration in a setting cement slurry in borehole-like conditions, early compression strength of a cement stone, corrosion resistance of cement stone in various deposit environments, porosity of cement stone, gas permeability of cement stone and rocks, chemicals content in drilling fluids, degree of chemical and drilling fluid toxicity using bacteria bioindicators;

- studies of the physicomechanical properties of rocks in terms of drillability.

\section{CONTACT}

Małgorzata Uliasz, PhD

Address: 3 Armii Krajowej Str., 38-400 Krosno, POLAND

Phone: +48134368941 extn. 5219 Fax: +4813436 7971

E-mail:malgorzata.uliasz@inig.pl

OIL AND GAS INSTITUTE

National Research Institute 